\title{
実験的変性軟骨の微細構造の変化について
}

（第一報）

新光園

九大整形外科

杉岡 洋一

\section{Ultrastructure of Articular Cartilage of Experimental Osteoarthritis}

By

\section{T. Wakimaru}

Shinkô-en Crippled Children's Hospital

\section{Y. Sugioka}

Department of Orthopaedics, Kyushu University

\begin{abstract}
A method is described for producing a slowly progressing osteoarthritis-like condition and permitting examination of even the earliest phases of degeneration of the articular cartilage in rabbit knee joints.

The method consists of making the joint unstable by surgical procedure; this produces a lesion of the same type as found in human osteoarthritis.

Degenerative changes produced was examined photomicrographically and electromicrographically.
\end{abstract}

われわれは変性軟骨の細胞レベルでの観察を意図し , 家象膝関節にいわゆる動摇関節をつくり, 関節の動 的平衡状態を破壊して, 变形性関節症を発生せしめ, 多少の知見を得たので文献的考察を加えてれを報告す る.

\section{実験結果及び結果}

$3 \mathrm{~kg}$ 前後の成熟雄家鬼に队側側副鞂帯と十字靬帯 の切離, 内側半月板の摘出を行い, いわゆる動摇関節 を作製し，機械的に変形性関節症を発生せしめ経時的 にその関節軟骨を光顕的電顕的に観察した。なお大腿 骨遠位端関節軟骨を荷重部之非荷重部に分け，乙れを パンチャーにて punched out して電顕試料に供し た. 術後 3 ケ月の X-P で, 大腿骨内顆部, 外顆部, そして内側の tibial plateau 辺縁部に osteophyte が見られるが，骨硬化や骨粗㯏ははっきりしない。 肉眼所見で, 手術側では, 大腿骨内顆中央荷重部に
Erosion が見られ軟骨面は本来の光択を失い非荷重部 の辺縁には chondrophyte といおうか肥厚した肉挈 組織様のものが見られる．正常膝関節内顆部の全割標 本で関節面は荷重部, 非荷重部共に平滑で辺縁部も丸 みを帯びている.術後 3 ケ月の内顆部の光顕所見で中 央荷重部では関節面は磨粍し, 内顆辺縁部の関節包付 着部では線維組織の増殖が著明で，丸みを失い鳥嘴状 になり, 軟骨下ょり血管侵入も認め, 将来 chondroosteophyte の形成が予想される.また関節面は篣状 にささくれ立った縌裂を認め（図 2 の）凸凹不整で ある。

正常関節軟骨の電䫒所見では（図一-1）平滑な関節 面に平行に配列した細長い電子密度の高い表首細胞が 見られ，中凰深風に行くに従って細胞は丸みを帯びて くる. また表㬝基質の fine fibers も概的関節面に平 行に配列して, 細胞構造も比較的明瞭である. 術後 3 ケ月の大腿骨内顆荷重部の電顕所見で（図一2）関節 
面は磨框し凸凹不整粗造となり，た めに表層細胞は関節挖に近くなり， 時には関節腔に露出する事もある. 細胞自身は境界不鮮明で, 電子密度 が高く黒くなり変性過程にあるもの と解される.とれらは典型的な dark cell と思われる.

非荷重部の光顕所見で本来の関節 面上に線維組織と思われる層が著明 に増殖して関節面を被い本来の関節 表風紐胞は至る 所壊死に陷ってい る.

その電顕所見では胞体が白く拔け ているのが本来の関節軟骨の壊死細 胞で核の境界もはっきりしない。こ の壊死細胞を拡大すると（図一 3 ） 細胞膜，核膜共に失われ，Myelin body や lysosome-like body が至 る所見られ，自己融解しつつある ものと思われる．との壊死細胞は shadow cell ともいわれる. 非荷 重部関節面を被っている線維組織の 電顕所見では, 本来の関節基質のも のより巾の広い collagen fibers の 中に生き生きした細長い線維芽細胞 が見られる，軟骨細胞の集り，いわ ゆる cell-cluster といわれるものが 変性過程に於ては, 極めてょく見ら れるが正常成熟軟骨ではまれにしか 見られない。この cell-cluster 中の 細胞は核や粗面小胞体をはじめ，細 胞諸官が明膫で紐胞活性に富んでい るように思われる。

\section{考}

案

些験的に変形性関節症を発生せし める方法に関する研究は, 従来幾多 の報告がある，例えば，関節の一部 を切除する方法，関節面を圧迫する 方法, 関節を固定する方法, proteolytic agent を関節腔に注入す る方法などである，Gardner は

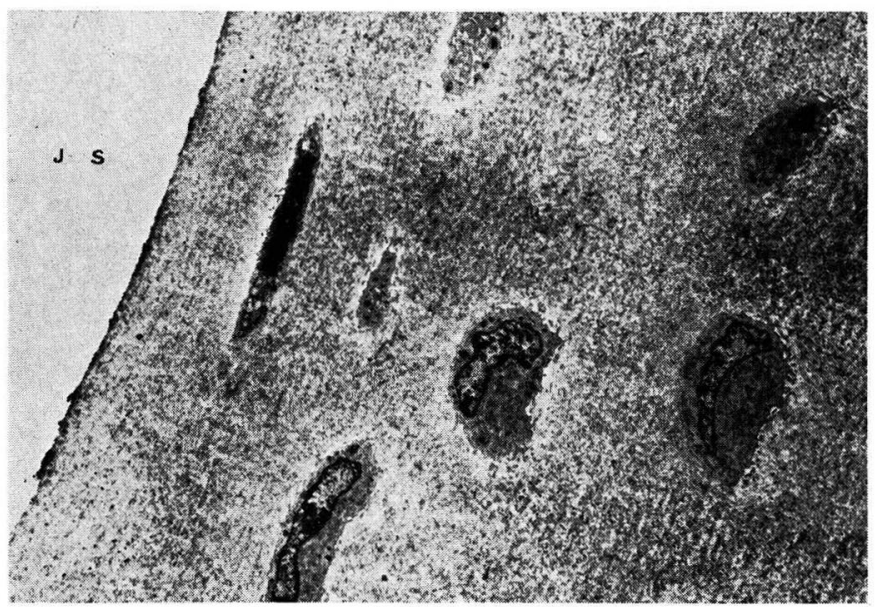

図一1 正常関節軟骨表首（コントロール群） $\times 2,000$ JS 関節腔

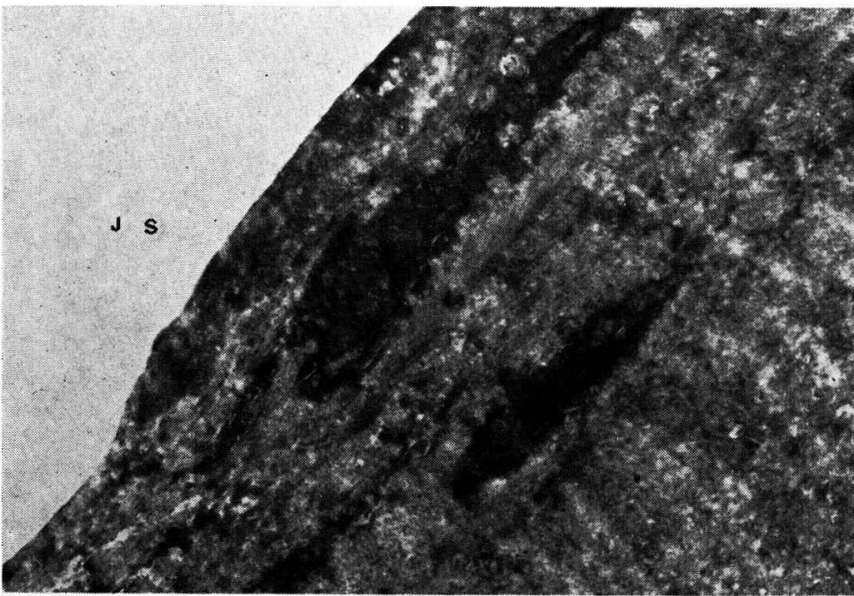

図一2 荷重部関節軟骨（手術群） $\times 10,000$ JS 関節腔

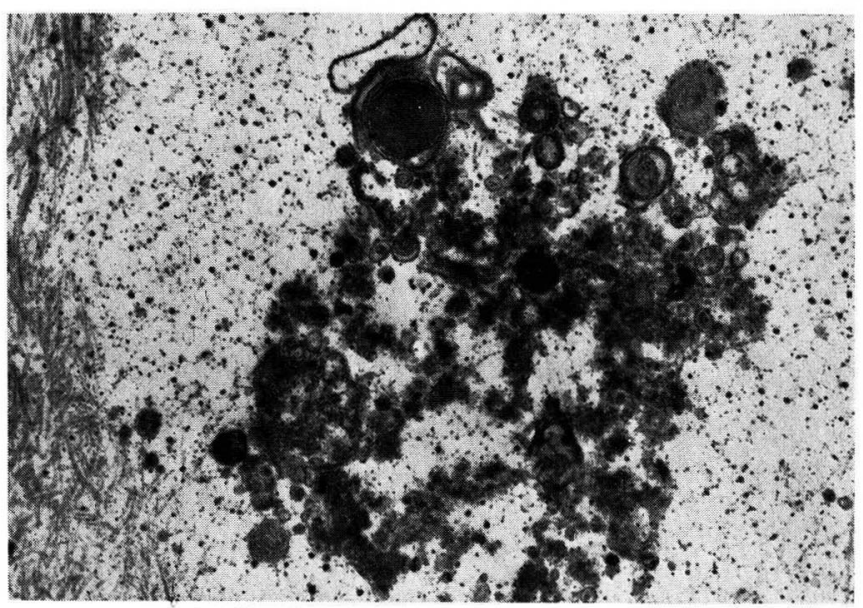

図一3 非荷重部変性関節軟骨 $\times 20,000$ 
1960年までにての種の文献を 300 例㴞猟したという. われわれがなぜての実験手技を選んだかというと， 1. 漱次進行性の 関節症をつくるのに適していて, early stage の状態を観察出来る事, 2. 手技が比較 的簡単な事, 3 . 変性所見が人間の関節症に酷似して いる事なごである.

本実験で問題となる点を要約し，考察を加える.

1.コントロール群, いわゆる正常軟骨の表層細胞 に見られる dark cell をどう解釈するか.

変形性関節症は勿論の事, 正常関節に於ても磨籷と 加令に伴う退行変性があり, この正常軟骨を電顕で見 ると, 電子密度の高い細胞全体が黑っぽく細胞諸器官 を明嘹に識別出来ない表㬝細胞がよく見られ，一般に dark cell と呼ばれるものに相当する. そしてわれわ れはこれを変性過程にある細胞と解釈した．電子密度 の高低により, この dark cell にも程度の差があるよ うで, これは変性の進行過程を表わしているように考 えられる.そして手術群荷重部軟骨にはこの dark cell が正常軟骨に比べ数多く見られる. また dark cell と同じように Micro-scar と呼ばれる線状の変 性細胞の残渣物も見られる。

2. 手術群非荷重部の本来の関節軟骨を被っている 線維組織の origin はどてか

正常関節軟骨面の辺縁部は synovial origin の薄 い膜で被われていて，中心部に行くに従ってての膜は 渐次消失しているという Fisher の説があるが，われ われはこの膜を 正常関節面では確認は出来なかった が, 一応この説に従うとすれば, 非荷重部（辺縁部） に快適な刺激が加わると, この膜に増殖性変化がおこ り，われわれの実験に見るように，本来の関節面上に 線維組織の首が光顕的にも見られるようになりてれは Synovial arigm 由来のものと想像出来る.

また肉眼的に軟骨下骨が露出していると見られる Erosion 部でも光顕的には軟骨下骨を薄く結合織が被 覆しているのが見られ，乙れは上述した手術群悲荷重 部関節面を被っている結合織と類似している点が多 く, どちらも再生力が旺盛であるように思われる.乙 れらの結果は関節軟骨の修復機転には synovial origin と bone marrow origin の結合織が関与してい るという Gurlt などの説に良く合致している.

3 . 非荷重部本来の関節軟骨の表風細胞や上部中層 細胞はなぜ壊死に陥りつつあるのか

関節辺縁部に於て chondro osteophyte が形成さ
れる時，てれに降接する軟骨細胞には垶死細胞がよく 見られるという Telhag などの報告や関節軟骨を切 除する実験に於て欠損部に隣接する軟骨細胞は欠損部 を結合識が修復するにつれて壊死に陥りやすいという Crauford などの報告などはわれわれの実験結果に類 似している. 何故壊死に陥るのかは不明である.なお 彼らはこの壊死細胞を shadow cell と呼んでいる. 今後の検索を必要とする所である.

4. 細胞の集り “cell-cluster” をどう解釈するか 正常成熟関節軟骨に於ても中間層や深首には時々こ の cell-cluster を見るが, 変性過程の一時期には全風 を通じて，著明に見られわれわれもてれを確認した。 果しててれが細胞分裂の一断面であるのか単に何らか の機転で細胞が集っただけなのか本実験からは結論出 来ない.一般には正常成熟関節軟骨（硝子軟骨）には Mitosis はおこらないという説が古来有力であるが， 機械的にしろ化学的にしろ, 適当な刺激が軟骨細胞に 加わると成熟細胞でも緩徐ではあるが Mitosis はお こりうるという説もある. また Mankin や Anders Hulth などは Radioautography を用いた実験でし の cell-cluster を Mitosis によるものであろうと報 告している。

唯, この cell-cluster 中の細胞は粗面小胞体をは じめ, 細胞諸器官が極めてよく発達して確認しやすく 細胞の Lifecycle からいえば，極めて生き生きした 青年期に当るものとしかわれわれの実験結果からは推 論出来ない.

\section{結㕵語}

われわれは変形性関節症を成熟家鬼に発生せしめ変 形性関節症という概念を改めて, 形態的に再確認し, 検討を加え，第一報としててれを報告した。

\section{文献}

1) G. Meachim, F. N. Ghadially and D. H. Collins: Ann. rheum. Dis. (1965), 24, 23.

2) Hans Telhag and Lars Lindberg: Clin. Orthop. No. 86, July-August, 1972.

3) Anders Hulth, Lars Lindberg \& Hans Telhag. Acta Orthop. Scand. 41, 522-530, 1970.

4) Thomas L. Gritzka, Lovis R. Fry, Roy L. Cbeesman: JBJS. Vol. 55-A, No. 8, Dec. 1973.

5) D.V. Daries, C. H. Barnett, W. Cochrane 
and A. J. Palfrey: Ann. rheum Dis. (1962), 21,11 .

6) C. H. Barnett, W. Cochrane and A. J. Palfrey: Ann. rheum. Dis. (1903), 22, 389.

7) Anderson, D. R.: Am. J. Anat. 114: 403433, 1964.
8) Silberberg, Ruth, Silberberg, Martin and Feir Devora: Am. J. Anat. 114: 17-47, 1964.

9) Palfrey, A. J. and Davies, D. V.: J. Anat. $100: 213-226,1966$.

10) Salter, R. D. and Fierd, P.: JBJS. 42-A : 31-49, Jan. 1969.

\title{
超音波断層法による四肢軟部組織病変の診断的意義
}

北里大学医学部整形外科
真 角 昭 吾・糸 満 盛 憲
中 島 啓 雅

臨床検査部

古木 量一郎

\section{Significance of Ultrasonic Examination for Orthopedic Diseases}

By

\author{
S. Masumi, M. Itoman \& H. Nakashima \\ Dep. of Orthopedic Surgery
}

R. Huruki

Dep. of Medical Laboratory

School of Medicine, Kitasato University. SAGAMIHARA.

\begin{abstract}
Ultrasonic imaging technique has advanced as important clinical examination for diagnosis of pathological processes within soft tissues.

In this paper, significance of ultrasonic diagnosis of orthopedic diseases was discussed in comparison with clinical, radiological and pathological findings. The cases include benign or malignant tumor, tumorous condition, cyst, swelling and abscess in soft part, and additionally bone tumors.

These tumors were scannd two-dimensionally with compound ultrasonic equipment. Sonic frequency is $2.25 \mathrm{MHz}$. Ultrasonic displays of benign conditions were imaged as homologous transparent structure with clearly defined contour. In malignant tumors, multiple sonic reflection which showed abrupt linear pattern or spotted one were presented antithetically to benign conditions. These benign and malignant echo patterns were closedly analogous to tumor section and the finding at operation.

Ultrasonotomographic displays received from different pathological processes give more useful diagnostic information in soft tissue diseases than that in bone tumors.

On the other hand, ultrasonic visualisation of bone tumor enclosed in osseous structure does not prevail the roentgen diagnosis.
\end{abstract}

最近臨床各科で超音波診断法がさかんに利用され， 日常検查法の $1 つ$ つつつある. わが国で超音波診 断法を骨格系に応用したのは西尾, 新宮らが最初であ
り，「整形外科領域における超音波探傷法の応用」と して骨折，膿煌，異物などについての知見が報告され ている $(1958,1959$ 年).一方順天堂大学の和賀井, 